\title{
A Theatre of their Own: Indian Women Playwrights and Directors in Perspective
}

\author{
Pinaki Ranjan Das \\ State/University Junior Research Fellow \\ Department of English, University of North Bengal, India
}

\begin{abstract}
That every individual is a performer in one way or the other, has preserved theatre from the threats of extinction and initiated its consistent progress. Theatre acts on a given moment and speaks directly to the audience; hence it has proved to be an effective medium of expression. Theatre has been among many other things propagandist, interventionist and also liberating. But it has also been criticized for not holding enough space for women to express themselves. The present paper addresses this issue in the light of Indian theatre, which has a long tradition but for the most of time remained a male preserve. It makes an incisive reading of the feminist theatre and goes on to critically look at the evolution of 'womanist dramaturgy' in the Indian context, in opposition to not just the male tradition but also the western feminist theatre. Exploring through the aesthetics put forward by the Indian women playwrights and directors, the paper tries to find or create a theatre of their own for the Indian women theatre practitioners, which ceases to be just a theatre of protest and ultimately establishes itself as a theatre of emancipation and of identity.
\end{abstract}

Keywords: Aesthetics, Drama, Theatre, Womanist Dramaturgy, Women's Theatre

\section{Introduction}

Theatre, being a medium which speaks directly to the audience, among many other things, falls in the public domain; and women, being traditionally considered fit to occupy the domestic space only, were kept away from articulating themselves through theatre. The same is true of Indian theatre too, which for centuries remained exclusive to men, but which, with the new surge of 'feminism' in the 1970s, opened up for Indian women effectively wide avenue for expressing their own voice. This not just resisted being devised by men but also strove to form a 'feminist' theatre. But feminist theatre, globally, was critiqued for indulging in essentialism and thereby becoming an instrument of oppression for women along class and caste lines. Indian women playwrights and directors struck a different note here by starting to construct a theatre which promised to uphold differences that separate women in one context from women in another. A study of Indian women playwrights and directors therefore, must be truly rewarding from historical, political and aesthetic perspectives.

\section{Drama and Theatre}

Before examining the distinctive dimensions of Indian and then Indian women's theatre, let us try to understand why defining theatre has never been easy, especially when it is considered in relation to drama. At best it can be taken as a space where meaning is formed in performance on stage (be it proscenium or not), constituted through a complex interaction of the body, words and such as costumes, designs, lights, techniques, and affecting the emotion and intellect of the audience. Conventional discussions on drama and theatre have resulted in pronouncing sharp distinctions between the two. It has been generally observed that drama being primarily textual is a more 'serious literary mode' (Knowles,526) which exclusively belongs to the playwright (notwithstanding the poststructuralist notions of the author and the text); while theatre being audiovisual belongs to the audience and is seen as "either the interpretative enactment of a stable, universal dramatic text or the translation of that text into different (usually unstable) codes of semiosis of enunciation, gesture, embodiment, design and so on'(Knowles,526). The play text has often been claimed by drama to be meant for reading, which opens up new vistas of meaning but which suffers constriction when reduced to a particular condition of performance in the theatre. However to theatre, the play text is just a script to which dimensions are added when it is performed. Critical understanding of drama/theatre has acquired complex dimensions over the years. The play text is not just limited to black marks on white paper but everything that entails knowledge, even performance itself. Conversely, performance brings in the body, which writes itself on the stage. There may be textual dialogues that the body delivers, but then the body itself also has its own language, for a body is never reduced to such a sign which refuses any connotation whatsoever. It not just bears the mark and meaning of its gender being conditioned by socio-cultural perceptions of it in particular locations of performance, but also itself produces meanings on the stage. The body has both an objective and subjective presence on the stage. "A performance takes one to another level of 'knowing'. What may be lurking within one in an incoherent shape, 
when echoed externally, comes sieved through a collective experience and changes its dimensions altogether. From the personal it becomes common knowledge - something that exists outside one - and being out in the open can be assuring as well as disturbing, if it challenges even a speck that lies dormant within."(Subramanyam, 146) Hence performance as text has initiated the emergence of a 'post-dramatic theatre' (21), where contemporary theatre practitioners like Maya Krishna Rao perform on stage without any written script. But then the advantage of having a well written script cannot be discounted. The debate may be settled temporarily by recognizing the 'hybrid existence'(Mukherjee,3) of the play text, which is written in order to be read and also performed, which not only adds multiple dimensions to the former, but also differentiates it from other genres.

\section{Modern Indian Theatre}

In the Indian context, theatre which was used by the colonial masters in the post-Sanskrit theatre period, 'to disseminate colonial culture and demonstrate cultural superiority, it became a powerful tool with which to challenge that very same colonial authority, both before and after India's independence' (Mee,4). In the conscious attempt to decolonize the modern Indian stage, theatre itself turned out to be not just a 'theatre of roots' but also a 'theatre of identity'. As Erin B. Mee observes, "Modern theatre came to be defined in terms of plot-driven plays that stemmed from a single author. It was expected to have human characters, conversational dialogue, behavior that was psychologically motivated, events that were causally linked, and realistic settings that allowed spectators to believe in the present tense reality of the action on stage and to identify with the characters, eliminating anything that would shatter the illusion of the fictional world of the play" (Mee,2). The Raj introduced not just the proscenium to the Indian theatre but also with its commercialization, transformed theatre into a 'commodity'. These 'created a cultural divide between what came to be seen as high/English/urban/modern /theatre and what was categorized as low/Indian/rural/traditional/performance'(Mee,4), though the divide was not as sharp as it appears. However, the 'theatre of roots' movement in its assertion of Indian identity, defined the modern Indian theatre in its own terms and hence challenged 'acultural definition of modernity and modern theatre in and on Western terms'(Mee,5).

\section{Indian Women's Theatre}

Yet modern Indian theatre, along with all the theatres of the past, has been critiqued on the ground that it has not held adequate space for women to express themselves. Most of the time, it has remained a male preserve. It is only from the late 1970s onwards, that we hear women 'speaking' in Indian theatre, not just as actors acting out their character on stage created by male playwrights and directors, but themselves composing plays and giving directions. This was also a kind of Indian response to the western feminist theatre which was emerging at the same time from experimental theatre groups and women's movements of the sixties and seventies: "productions and scripts characterized by consciousness of women as women; performance (written and acted) that deconstructs sexual difference and thus undermines patriarchal power; scripting and production that present transformation as a structural and ideological replacement for recognition; and the creation of women characters in the 'subject position'... It was exciting because it dared to venture to the stage with such diverse and sometimes surprising representations and explorations of women, of their relationships to each other and to men, that it created a new audience for theatre"(Keyssar,1). Among many other things, what it has most importantly proposed is the idea of a 'women's language' and its possibilities of creating altogether a new kind of narrative in theatre. The feminist theatre has also entailed a rethinking of plot/character configuration, putting into question the 'meaning and performance of character both on stage and in script'. 'Direct action' and consistency in logical building of the plot gave way to indirect actions and inconsistencies and disjointedness in plot constructions. Non-linear plots, refusing any kind of resolutions aided in challenging the socio-political normativity that entailed continuation of artificial boundaries between gender, class, race, culture etc. In its pursuance of feminist themes, it questioned male dominated discourses and challenged institutions forcing confromity. It goes so far as to foreground "the genderization of culture and over determination of sexuality, both which is instrumental in the subjugation of women, the repression of female subjectivity" (Forte,232). Amidst all these graces, feminist theatre, much like feminism itself, has been critiqued for being 'essentialist', that is, for reducing women to bodies, and for assuming that 'all men are the same'. Hence, the objectified and categorized representation of women has continued, though the objective was to foreground women as subjects. In trying to hinge on to the demands of the organized women's movements, the feminist theatre, instead of 'reevaluating' women's role in society, thrived to substitute a whole new set of social structure that would aim to redefine the conventionally established male-female configuration. The feminist alignment in theatre has even been critiqued as 'a grouping unified by its political interests, not its common experiences'. Hence in the post 1980s period, we find the fresh emergence of women playwrights and directors, who were initiated not by political but general 'concern for gender relations' (Mukherjee,14). They drew upon essential women 
experiences aimed at 'consciousness raising' (14) among women in order to effect socio-political development for them. It is the 'feminine awareness' that is most strikingly aimed at in the plays. Though the women's theatre was borne out of the feminist theatre of 70s, it is actually a kind of maturation into the more conscious and confident 'female stage', from the feminist stage, which in its pursuit of the political aims, run the danger of being polarized in such a way as to be in total opposition to the conventional 'gender structure'(14).

'Women' have been culturally constructed as 'objects'. They have been categorized as the 'Other', a derivative of the socially dominant male subject. It is this position of being in the other which makes it representational, and hence her 'presence' on stage in conventional roles. This contributes to women's status quo, though feminist theatre started presenting their resistances, too. The political orientation of the feminist theatre would foreground the issues of subversion, but then at the same time in the production of the new politically conscious woman, it would again be guided by the discourses already maneuvered by the institutions of patriarchy. Hence, while standing in total opposition to the convention, it would try to construct its own self with respect to the other (that is the male tradition), but then it would again get othered, for meaning ultimately would flow from the other, which had traditionally been and would again be reinstated in the position of the self, at this time with the apparent agency of the feminist politics.

In foregrounding women's experiences and sexuality on stage, not in opposition to the male counterparts but in focusing on their own exclusivity and uniqueness in perceiving the world at large, women's theatre presents the woman as a "speaking subject". Hence it throws into doubt the private/public divide where the public ceases to be the exclusive domain of men. In presenting women as subjects, as conscious choice and decision makers, women's theatre moves away from the essentialism in feminist theatre, for it takes into account multiple contexts of the women all over and the differences in their socio-cultural conditioning that differentiates one woman from the other. Hence, women's theatre emerges as an alternative to the conventional theatre, not necessarily taking a political stance against it, as was the case with feminist theatre.

In the Indian context, the role of women's theatre is more crucially conceived, owing to the complex locations of women amidst the cultural diversity of the country. From the 1980s onwards, we find the emergence of a host of women playwrights and directors populating the list of practitioners in Indian theatre, which has traditionally been a male preserve. Their plays strive to present, amid the varied women experiences which is not devoid of struggles against domination, Indian women's hopes and aspirations, their fulfillments or frustrations, subject to the conditions they live in. These can be further correlated with the lived experiences of the women playwrights and directors themselves. In order to dramatize these issues effectively, they make use of history, mythology or ancient accounts of life and society, by way of reinterpreting them from women's point of view. They have consistently used folk themes to their own advantage, and used drama as an effective medium to analyze socio-cultural differences and issues associated with gender discrimination.

\section{Aesthetics Of Indian Women's Theatre}

The plays, written and directed by the contemporary women playwrights and directors, when taken as a whole, can be said to evolve a 'womanist dramaturgy' (Mukherjee,17) that creates its own paradigms. A history of women's participation in theatre, at least in the Indian context, would reveal that it is a result of the process of gradual unfolding of conservative Indian society's male preserves for women. Initially, young men without beards were used to perform women's roles on stage. Women's participation all began with the devadasi tradition in a sense, where women's performances, though primarily aimed at pleasing a male deity, thereby hinting at patriarchal legitimization as well as exploitation of women's art, nevertheless, allowed women to carry on with their art. The female exclusivity inherently present in this tradition, initiated the whole process of acting on the stage, where they had to enact what was already scripted for them by male playwrights and directors. Things somewhat changed with women playwrights' and directors' entry into the field of theatre in India, and then took several turns along the way. The first phase was one of the imitations of male dramaturgy modes of representation and theatre practice, which earned the women theatre practitioners some recognition from male theatre critics, practitioners and the audience. The second phase can be described as women practitioners' critical sensitivity towards the male theatre traditions and the third phase has begun with the articulation of the women-centric concerns, where the women playwrights and directors are not just exploring the nuances and ramifications of women experiences and desires but also celebrating their differences. The womanist dramaturgy, thus evolved, is neither the outright rejection of traditional theatre forms because they also can be used to present the nuanced locations of women in the complex Indian contexts, nor is it the merely experimental theatre forms and non-linear plays as exemplary of women's theatre. It is as, Helene Keyssar says, projecting the 'consciousness' of women as women and what it means to be in the position of the 'subject', while being also aware of the otherness. Hence, the womanist dramaturgy emerges as the shift in stance, where it is not dependent on the patriarchal recognition or identity. 
Traditional theatre, following the classical ideas of 'realism', aimed at presenting the world in such mimetic ways as to dissolve any sort of division that may subsist between the audience and the stage. Hence, representation of women, their struggles and lived experiences, would never be complete because, theatre would strive to draw a resolution which would lead to catharsis at the end. But women's theatre would not aim to achieve such social and emotional equilibrium by foregrounding the make-believe realist world. It would rather aim at subversion, a kind of disruption and departure instead of involvement. It would renegotiate accepted realities and put forward contradictions, 'circularity' and 'multiple viewpoints'. It might also make a special use of Brechtian techniques such as the gest, epic structure, and alienation effect in order to create a rupture in the 'unified whole'. Indian women playwrights and directors' are evolving a dramaturgy so as to open space for multiplicity of voices, plurality of contexts, new languages, new forms, new perceptions that would help women to articulate their own experiences, hopes and struggles. Western feminism, if something like that exists, had considerable influences on them, but they consciously deviated from the monolithic, singular worldview and are more concerned with presenting history and context specific women's issues. The dramaturgical innovations and the thematic concerns of Indian women theatre practitioners have constructed a theatre of their own that speaks women in wider perspectives.

\section{Conclusion}

However, this development has not been documented well, for there remains negligible presence of women playwrights in the print medium. This is in stark opposition to the other genres such as fiction, nonfiction prose or poetry. Even contemporary anthologies, such as Chandrashekhar Kambar's Modern Indian Plays (NSD,2000) ignores the women playwrights altogether, while G.P. Deshpande's Modern Indian Drama: An Anthology (Sahitya Akademi,2000) gives space only to a male translated version of Mahasweta Devi's The Mother of 1084. Only Erin B. Mee in her Drama Contemporary India (PAJ Books, 2001) presents two women playwrights among the six she selected for her anthology. However, recent publication of some of the anthologies such as Women, Centre, Stage(Routledge,2010) Body Blows: Women, Violence and Survival (Seagull Books, 2000) and Tutun Mukherjee's Staging Resistance: Plays by Women in Translation (OUP,2005) do exclusively deal with plays written by women playwrights but they are far from being adequate. The increasing popularity of women directors too has not redressed the problem, since much of their success has depended on adaptations of the plays written by the male playwrights. Hence the above area of concern would provide enough scope for research with the promise that critical explorations in this field, in order to find or create the Indian women's theatre, if not exclusively original, would be one of the foremost contributions to this area. For, women's theatre in India has opened up new vistas at the thematic as well as aesthetic level. It is not only about achieving freedom through theatre but also about the responsibility of voicing the socio-cultural and political condition of women in India, without being essential in presentation.

\section{References}

[1]. Knowles Ric, 'Modern Drama: Defining the Field', Modern Drama, Vol. XLIII, No. 4, (Canada: University of Toronto Press, 2000)

[2]. Subramanyam Lakshmi , Muffled Voices: Women in Modern Indian Theatre (India: Har-Anand Pub., 2002)

[3]. Mukherjee Tutun, Staging Resistance: Plays by Women in Translation (India:Oxford University Press, 2005.)

[4]. Mee Erin B., Theatre of Roots: Redirecting the Modern Indian Stage (India: Seagull Books, 2008)

[5]. Helene Keyssar, Feminist Theatre and Theory (U.K.: Palgrave Macmillan,1996)

[6]. Forte Jeanie, Women's Performance Art: Feminism and Postmodernism, Theatre Journal, Vol. 40. No.2,( The Johns Hopkins University Press, 1988) http:/www.jstor.org/stable/3207658 (accessed on 26/02/2014 02:22) 